\title{
Exponential Nitrogen Fertilization of Luehea divaricata Mart. Seedlings
}

\author{
Deisinara Giane Schulz ${ }^{1}$ \\ Michelle Cristina Ajala ${ }^{2}$ (]) \\ Micheli Angelica Horbach ${ }^{2}$ (1) \\ Ubirajara Contro Malavasi ${ }^{3}$ (1) \\ Marlene de Matos Malavasi ${ }^{3}$ (C)
}

\begin{abstract}
Nutritional balance interferes positively in obtaining high-quality seedlings of wood species. This study aimed to evaluate nitrogen fertilization during the production of $L$. divaricata seedlings. The experiment was conducted in a shade house located at $24^{\circ} 33^{\prime} \mathrm{S}$ and $54^{\circ} 04^{\prime} \mathrm{W}$, in a randomized block design formed by two forms of fertilization plus a control applied during three months, totaling nine applications, with seven replicates of five seedlings each. Both exponential and conventional fertilization regimes supported the hypothesis of growth induction of $L$. divaricata seedlings in relation to the control during the growth phase, with exponential fertilization as a valid option to reduce initial nutrient loss by leaching.
\end{abstract}

Keywords: seedling production, method of fertilization, quality seedlings.

\section{INTRODUCTION}

The productive sector of native forest essences in Brazil has aroused interest in the production of seedlings destined for commercialization, and you must guarantee the quality respecting the particularities of each species. The species present a variable demand in the different growth phases, mainly in relation to light, nutrients and humidity, and the way of management in nursery fertilization can strongly influence the morphology and physiology of the seedlings and, consequently, the postplanting performance (Scremin-Dias et al. 2006).

Fertilization, substrate, propagation environment, container volume, irrigation and correct management of production operations have been crucial for obtaining seedlings with high quality, in order to ensure success in field development (Costa et al. 2015). Li et al. (2016) emphasized that mineral nutrition of plants is among the most important attributes for obtaining quality seedlings for planting of temperate forests. Villar-Salvador et al. (2012) have also argued in favor of the importance of mineral nutrition for the survival and growth of seedlings, supporting eco-physiological relationships between seedlings and post-planting responses. According to Uscola et al. (2015), an optimal fertilization regime promotes seedling growth and nutrient loading without toxic effects.

Nevertheless, fertilization has a high cost for nurseries, associated with a high loss of fertilizers in the initial process of seedling formation and lack of nutrients in the final process. In order to reduce such damages and obtain seedlings of higher quality and hardness, Villar-Salvador et al. (2012); Oliet et al. (2013); Cortina et al. (2013) and Fu et al. (2017) have adopted and tested alternative methods of fertilization which result in increased seedling growth and survival. They teste the so-called controlled or exponential release fertilization which is designed as a regular increase of nutrients, in which plants should grow with an internal and constant concentration of nutrients, and free from nutritional stress.

Exponential fertilization, when compared with conventional fertilization (fertilization rate is constant) was investigated by Oliet et al. (2009) in Quercus ilex L. seedlings resulting in differences between the seedlings fertilized by the conventional

\footnotetext{
${ }^{1}$ Escola Estadual Professora Nair Palácio de Souza (EEPNPS), Nova Andradina, MS, Brasil

${ }^{2}$ Universidade Estadual do Oeste do Paraná (UNIOESTE), Marechal Cândido Rondon, PR, Brasil

${ }^{3}$ Universidade Estadual do Oeste do Paraná, Marechal Cândido Rondon, PR, Brasil
} 
method and those fertilized exponentially at the dose of $100 \mathrm{mg} N$ per plant.

Dumroese et al. (2005) found with Pinus monticola Dougl. ex D. Don that exponential fertilization (20 mg N per plant) compared to conventional fertilization ( $36 \mathrm{mg} \mathrm{N}$ per plant) resulted in higher growth rates, better nutrient uptake efficiency and reduced nutrient amounts discharged in the soil.

Lopez (2012) in a global study, the variable indicating the best development and survival is aerial biomass, and exponential fertilization with nitrogen in nursery has shown two or seven times greater growth and biomass, especially in fast-growing species, in addition to nitrogen exponential ferlization can improve seedling nutritional quality and field survival.

Luehea divaricata (C. Martius) (Tiliaceae) is a pioneer species from South America, frequently used in reforestation programs in Brazil, being found from north to south of the country in river regions and forests, thus contributing to soil drainage and restoration (Scheer et al., 2017).

This study aimed to evaluate application of nitrogen fertilization during the production of $L$. divaricata seedlings.

\section{MATERIAL AND METHODS}

The experiment was carried out in protected cultivation area located at $24^{\circ} 33^{\prime} \mathrm{S}$ and $54^{\circ} 04^{\prime} \mathrm{W}$, altitude of $420 \mathrm{~m}$ during 2012 and 2013.
Local climate is characterized as subtropical humid, classified as $\mathrm{Cfa}$, according to the Köppen climate classification, with hot summers, infrequent frosts and tendency to concentrate rainfall in the summer months. The dry season is not defined, mean annual rainfall is $1,500 \mathrm{~mm}$, mean annual humidity is $80 \%$, and the annual mean temperature is $21^{\circ} \mathrm{C}$, with a mean maximum of $28^{\circ} \mathrm{C}$ and a mean minimum of $15^{\circ} \mathrm{C}$. During the experiment the mean temperature ranged from $14^{\circ} \mathrm{C}$ to $37^{\circ} \mathrm{C}$ and the mean humidity from $28 \%$ to $60 \%$, which were measured using a self-programmed temperature and humidity datalogger.

L. divaricata seedlings were propagated by seeds, collected from fifteen trees located in areas of native vegetation in the West Region of Paraná by collectors from the Nucleus of Experimental Stations of UNIOESTE, in $120 \mathrm{~cm}^{3}$ plug filled with commercial substrate (Mecplant ${ }^{\circ}$ ) without basic fertilization, distributed in plastic trays with 96 cells placed on a metal frame $1,0 \mathrm{~m}$ from the ground. Seedling fertilization lasted for 7 months.

When the seedlings presented height of $10 \mathrm{~cm} \pm 2 \mathrm{~cm}$ we started treatments. One hundred and ninety seedlings were submitted to gradual exponential fertilization (Figure 1), using as reference seed $\mathrm{N}$ content $(0,79 \mathrm{mg})$ and reaching final concentration of $100 \mathrm{mg} \mathrm{L}^{-1}$ of N per plant (Oliet et al., 2009). Other 35 seedlings were submitted to conventional (or constant fertilization) of $100 \mathrm{mg} \mathrm{L}^{-1}$ of $\mathrm{N}$ per plant $(11,1 \mathrm{mg} \mathrm{N}$ ) every 10 days during three months, while other 35 seedlings were not fertilized (control seedlings).

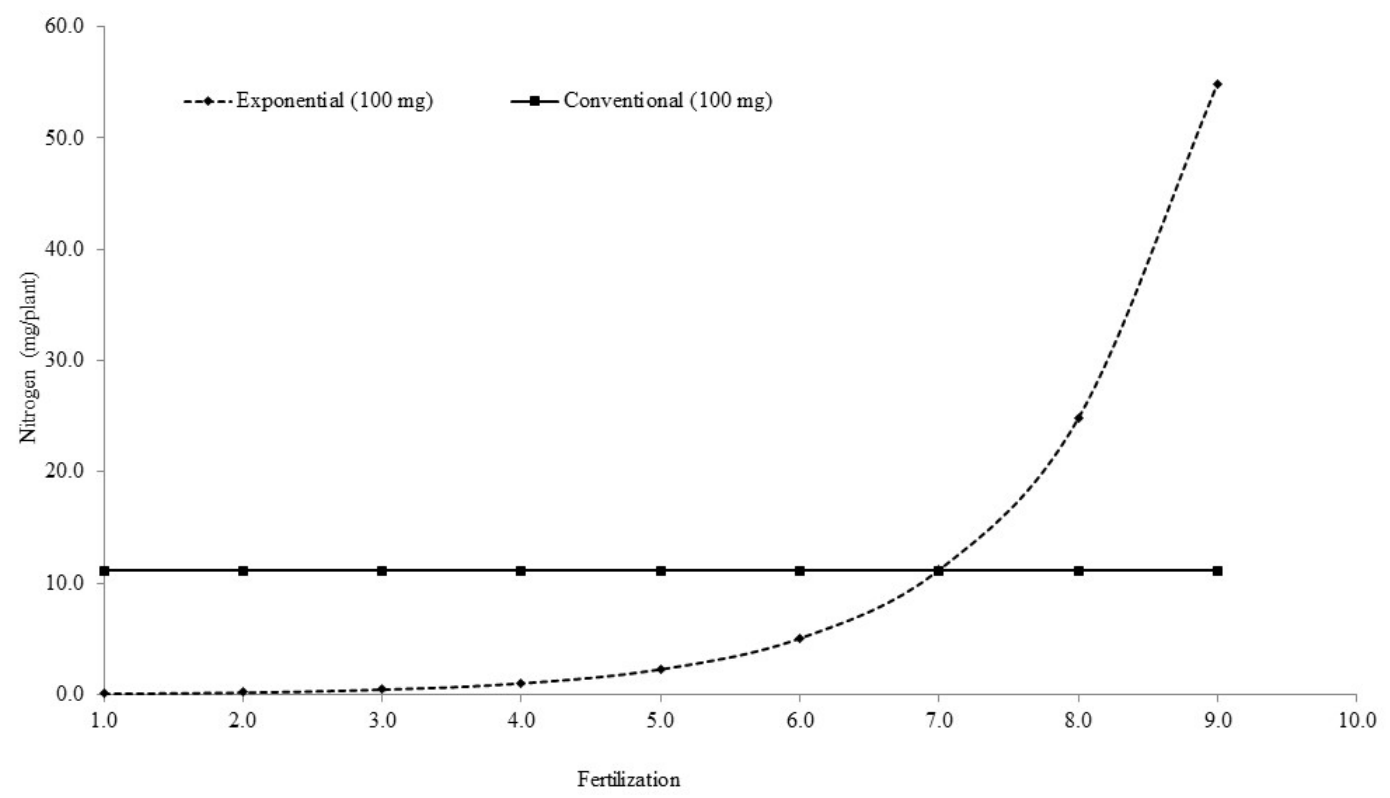

Figure 1. Gradual exponential and conventional fertilization reaching final concentration of $100 \mathrm{mg} \mathrm{L}^{-1}$ of $\mathrm{N}$ in $L$. divaricata seedlings. 
Seedlings recieved the treatments manually at 8 AM daily until finishing the applications, using a solution with urea (45\%) applied with a dispenser. Other nutrients were also provided for all seedlings at concentrations $\left(\mathrm{mmol} \mathrm{L}^{-1}\right)$ of $0.9 \mathrm{H}_{2} \mathrm{PO}_{4}^{-} ; 2.25 \mathrm{SO}_{4}$; $10.0 \mathrm{Ca}^{++} ; 6.0 \mathrm{~K}^{+}$and $5.0 \mathrm{Mg}^{++}$, and in $\mathrm{mg} \mathrm{L}^{-1}, 0.42 \mathrm{Mn} ; 0.26$ of $\mathrm{Zn} ; 0.05 \mathrm{Cu} ; 0.50$ of B; $0.04 \mathrm{Mo}$, and $4.82 \mathrm{Fe}$-chelate.

When the seedlings presented signs of competition, we reduced the number of seedlings per tray to 48 . Seedlings received irrigation three times a day always in the morning and at the end of the afternoon according to the relative humidity.

The electrical conductivity of the substrate prior to fertilization was 760, 397 and 400 for the control, exponential and conventional regimes, respectively.

We measured seven replications of five seedlings per treatment by the end of the development phase (i.e.90 days). Measurements included stem diameter $(\mathrm{mm})$, seedling height $(\mathrm{cm})$, number of leaves and leaf area (using Image $)^{\circledR}$ in which the images being scanned through a digital photo camera placing the sheets on a white board with a $2 \mathrm{~cm}$ mark for later calibration), and SPAD index (using a Minolta Spad-502) of four leaves (located in the median crown) per seedling. In addition, were quantified shoot (SDM) and root (RDM) dry biomass from ten seedlings per treatment using an air circulation oven at $60^{\circ} \mathrm{C}$ for 72 hours. Root volume was determined by water displacement, as well as we calculated height to diameter ratio (H/D) and Dickson quality index (DQI) according to the following equation:

$$
D Q I=\frac{\mathrm{TDMg}}{\frac{H \mathrm{~cm}}{D m m}+\frac{S D M g}{R D M g}}
$$

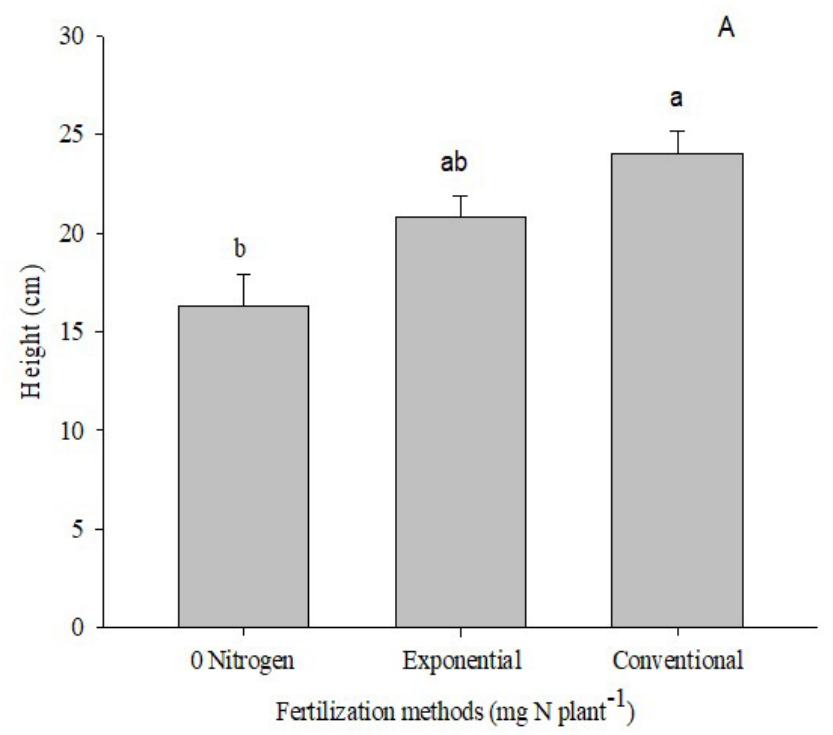

The dry matter obtained was ground in a Wiley mill and passed through a 40-mesh sieve for quantification of nitrogen $(\mathrm{N})$, phosphorus $(\mathrm{P})$ and potassium $(\mathrm{K})$ contents in the leaves. To evaluate the $\mathrm{N}$ and $\mathrm{P}$ contents in the plant tissue, $0.2 \mathrm{~g}$ samples were used in four replicates per treatment, which were submitted to sulfur digestion and subsequent distillation in a semi-micro Kjeldhal. We used UV-Vis spectrophotometry for determination of $\mathrm{N}$ and $\mathrm{P}$ while $\mathrm{K}$ used flame photometry.

The data were tested for normality and homogeneity (Barllet and chi-square, respectively) for subsequent analysis of variance. When necessary, treatment means were compared with Tukey test at $5 \%$ probability. Three fertilization treatments were evaluated with seven blocks by treatments with five seedlings per block, with the aid of the Genes program (Cruz, 2013).

\section{RESULTS AND DISCUSSION}

Fertilization regimes of $L$. divaricata seedlings influenced growth dynamics. There was a significant effect $(\mathrm{P}<0.05)$ on seedling height, stem diameter, SPAD index, height/diameter ratio (H/D), and $\mathrm{N}, \mathrm{P}$ and $\mathrm{K}$ content.

Seedlings fertilized conventionally with $100 \mathrm{mg}$ of N per plant were taller than those exponentially fertilized. Control seedlings showed the lowest seedling height (Figure 2A). Stem diameter was smaller in control seedlings than both conventional and exponentially fertilized seedlings (Figure 2B).

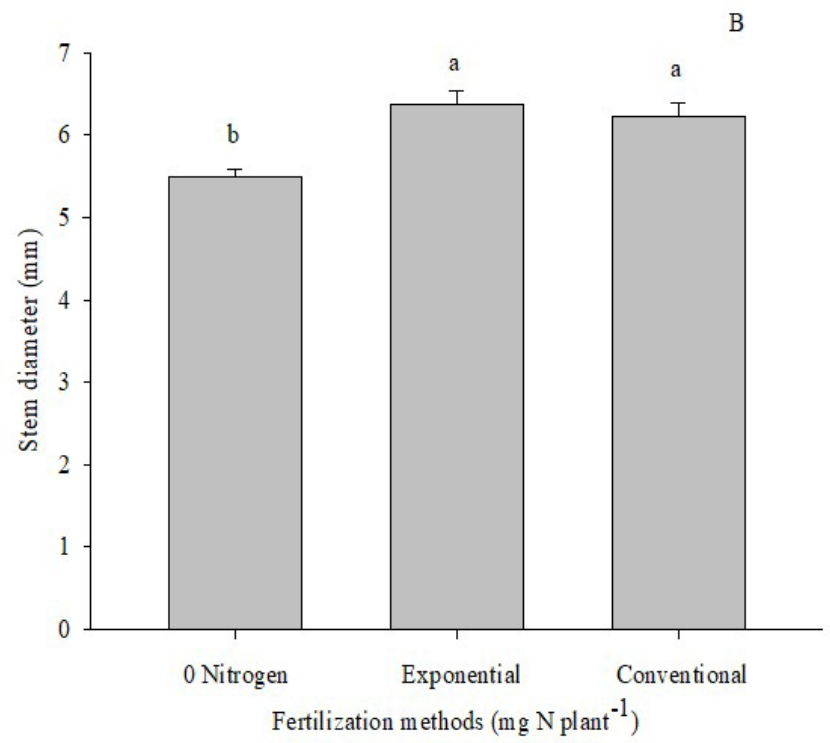

Figure 2. Height and diameter of the stem of L. divaricata submitted to different nitrogen fertilization regimes. Mean values followed by the same letter in the bars of the same color do not differ among themselves by the Tukey test at $5 \%$ probability. 
The above-mentioned results agree with a review from Oliet et al. (2009) who obtained similar trends when comparing conventional and exponential fertilization of $70 \mathrm{mg}$ of $\mathrm{N}$ in both treatments, in which the conventional system showed greater growth. Similar to the results of this study, Schmal et al. (2011) reported higher height values of Quercus robur L. seedlings fertilized exponentially with 1,880 $\mathrm{kg} \mathrm{ha}^{-1}$ of nitrogen when compared to non-fertilized seedlings.

There were no differences of RDM and SDM values from seedlings grown under the two fertilization regimes (Figure 3A). Contrary to the above findings, Oliet et al. (2009) with Q. ilex reported $67 \%$ and $42 \%$ higher RDM for conventionally and exponentially fertilized seedlings respectively and an increase of $73 \%$ and $35 \%$ SDM for seedlings not fertilized with nitrogen. Our results showed that root volume was the same for all treatments (Figure 3B). These results can be explained in functions of the root system that are less sensitive to nitrogen applications, without compromising root development, since all tests are performed as potassium and phosphorus candies, or even by limiting root growth by using it. . Although it did not show significant averages, it can be observed a greater development in the SDM, which may indicate that the seedlings have accumulation or nitrogen in the aerial part of the seedlings.

The exponential and conventional treatments showed differences for SPAD index compared to control seedlings (Figure 3B). According to Sant'ana et al. (2010), SPAD index provides an instant, non-destructive reading of chlorophyll content. Additionally, chlorophyll content correlates with $\mathrm{N}$ concentration in the plant and crop productivity (Klooster et al., 2012). The results of the highest SPAD values in plants grown under exponential and conventional fertilization suggest a higher concentration of nitrogen in the leaves or that also requires vegetative vigor, and possibly a greater mobilization of nitrogen when necessary, since nitrogen is an essential part of amino acids and chlorophyll, thus contributing to the photosynthesis and growth of seedlings. Acoording to Villar-Salvador et al. (2013), the ideal fertilization protocol should allow an adequate growth of seedlings, but it should also promote the existence of high levels of nutritional reserves, so that plants are able to develop satisfactorily, even when the availability of nutrients in the place of planting is already limited.

We detected no differences $(\mathrm{P}>0.05)$ for number of leaves, leaf area (data not shown), DQI (Figure 4A) and root volume of $L$. divaricata seedlings submitted to nitrogen fertilization treatments. The lack of differences between the treatments may have occurred because of leaching from the substrate, or because the species used is characteristics as being a heliophyte. This can be explained by the constraint imposed by the container according to Uscola et al. (2015) to whom the smaller the container the less the permanence of the elements in the substrate leached at the time of irrigation. Those statements corroborate the description given by Dumroese et al. (2005), who emphasized that the increase in fertilizer addition may cause higher leaching losses of $\mathrm{N}$.
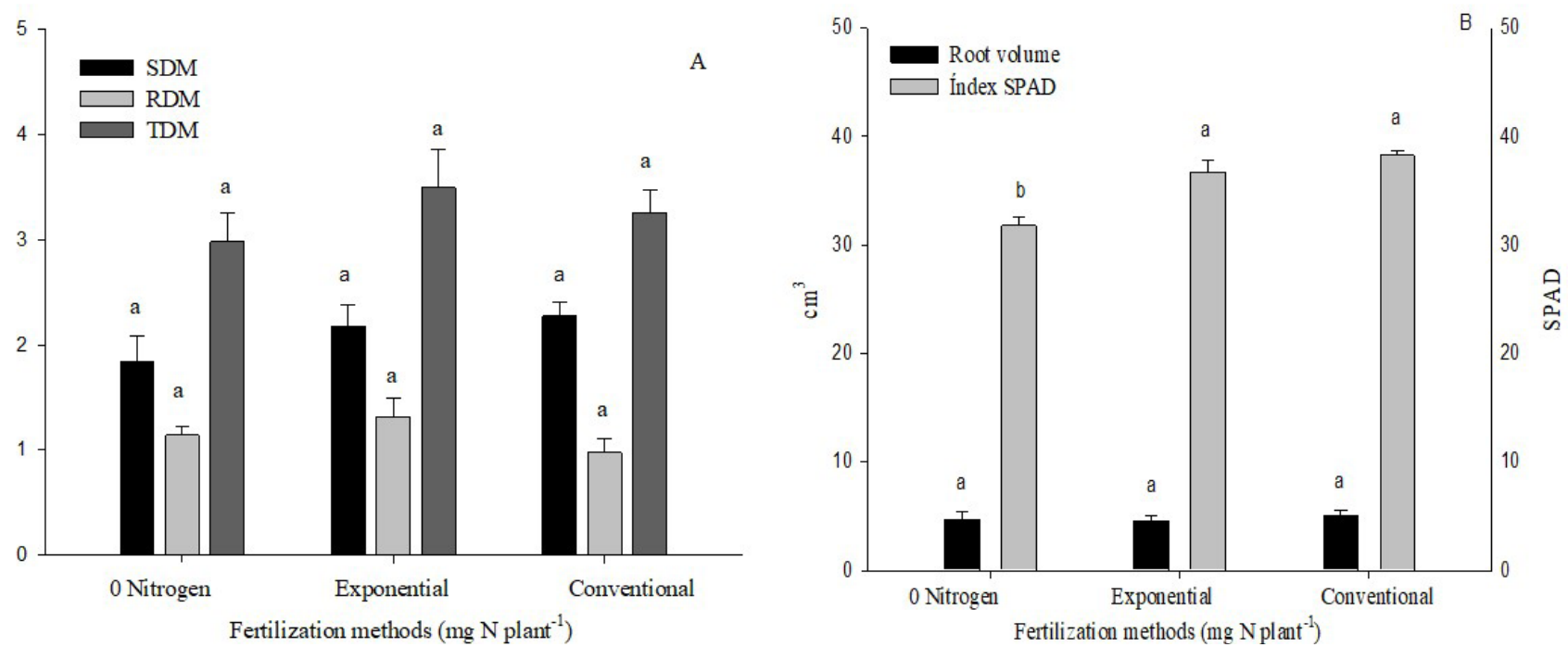

Figure 3. Shoot dry mass (SDM), root dry mass (RDM) and total dry ass (TDM) (A) and root volume and SPAD index (B) of L. divaricata submitted to different nitrogen fertilization regimes. Mean values followed by the same letter do not differ among themselves by the Tukey test at $5 \%$ probability. 
There were differences $(\mathrm{P}<0.05)$ for $\mathrm{H} / \mathrm{D}$ and SDM/RDM ratios as a function of fertilization treatments, in which control seedlings (i.e. without addition of nitrogen) were affected in relation to growth, resulting in lower values for H/D and SDM/RDM (Figure 4B). The H/D ratio also known as stiffness suggests a relationship between quality and strength, in which the larger the value the smaller the stem diameter (Caldeira et al. 2012). The same reasoning can be applied to the SDM/RDM ratio, which results in seedlings that were conventionally fertilized with etiolation of the aerial tissues in relation to the stem and root system indicating an imbalance in the H/D ratio. Since L. Divaricata seedlings respond well to two forms of fertilization of $\mathrm{N}$ supplies, showing no symptoms of $\mathrm{N}$ toxicity, an explanation for these results would be a low concentration of $\mathrm{N}$ in the seeds, as well as a pioneer and fast-growing species, and use a large initial amount of $\mathrm{N}$.

The H/D ratio must be less than 10 as recommended by Delarmelina et al. (2014) with Sesbania virgata (Cav.) Pers. seedlings, who reported values between 3 and 5 similar to those obtained with $L$. divaricata seedlings in the present study. The SDM/RDM ratio of Tectona grandis seedlings should be less than 2 according of Caldeira et al. (2012). Thus, exponentially fertilized seedlings presented those values and conventionally fertilized seedlings had higher ratios than those.

Nitrogen content of exponentially and conventionally fertilized seedlings were 2.89 and $2.72 \mathrm{mg} \mathrm{g}^{-1}$ respectively or a $32 \%$ increase compared to control seedlings (Figure 5A). Those results agree with Oliet et al. (2009) who tested $100 \mathrm{mg}$ of $\mathrm{N}$ fertilization in Q. ilex seedlings provided exponentially and conventionally and reported an increased $\mathrm{N}$ content of $116 \%$ and $110 \%$ compared to non-fertilized seedlings.

These results suggest that the greater availability of $\mathrm{N}$ in the substrate enabled its accumulation in the plant and thus the availability for times of stress, although there is no difference between exponential and conventional fertilization in this variable.

Additionally, Dumroese et al. (2005) reported that the efficiency of nutrient uptake in exponential cultivation was higher than in the conventional system. Those authors suggested better synchronization between supply and demand in exponentially fertilized seedlings. In this study, the efficiency of $\mathrm{N}$ uptake was $75 \%$ in exponentially fertilized seedlings compared to $50 \%$ in conventionally fertilized seedlings.

Phosphorus in terrestrial plants stimulates root growth, guaranteeing a vigorous initial development and survival capacity (Cuesta et al., 2010). The quantified phosphorus levels were different in seedlings subjected to the tested treatments. The highest values were quantified in control seedlings and in the conventional fertilization regime (Figura 5A). For Grohskopf (2017), N and P interact synergistically, and the greater the nitrogen fertilization in the soil, the greater the demand for P. This relationship between PxN absorption shows that seedlings grown under the exponential regime, possibly showed lower initial $\mathrm{P}$ absorption, and later when there was a greater supply of $\mathrm{N}$, the levels of $\mathrm{P}$ remained lower compared to conventional and zero $\mathrm{N}$ cultivation, as it increased the electrolyte concentration promoted chemical changes that interfere with the greater or lesser availability and diffusivity of P.

Likewise, for the $\mathrm{K}$ content, there were differences $(\mathrm{P}<0.05)$ between the control seedlings compared to the two nitrogen fertilization treatments, with the highest $\mathrm{K}$ values quantified from leaves of control seedlings (Figure 5B). These results also agree with those from Moreira et al. (2009) who verified an inverse interaction between $\mathrm{N}$ and $\mathrm{K}$. Corroborating this statement it was observed that when there is a supply of $\mathrm{N}$, there is a dilution in the $\mathrm{K}^{+}$in the plant, since the two nutrients are not competing in absorption, but in the presence of an increase in potency in the absorption of $\mathrm{NH}_{4}^{+}$, a result observed in the highest value of $\mathrm{K}$ in plants that did not receive nitrogen fertilization (Figure 5B).

Phosphorus content from $L$. divaricata leaves showed differences $(\mathrm{P}<0.05)$ between exponential and conventional fertilization regimes. The highest values resulted from conventional fertilization and control seedlings when compared to exponential fertilized seedlings. Dumroese et al. (2005), in similar comparisons for $P$ and $K$ contents, reported different results for $\mathrm{P}$, with accumulation of $19 \%$ versus $12 \%$ and $\mathrm{K}$ accumulation at $56 \%$ versus $35 \%$ in exponential and conventional regimes respectively which differ from those of this study.

Exponential fertilization match growth requirements and should improve the efficiency of fertilizer use in nurseries, comprising an alternative for application of the least amount of nutrients and less initial loss by the seedlings. Nevertheless, some disadvantages of exponential fertilization include initial nutritional analysis from seeds, fertilization calculations according to species and greater time and work necessary for application of fertilizer.

Studies comparing doses of exponential fertilization with field work are recommended to evaluate seedling survival and growth. 

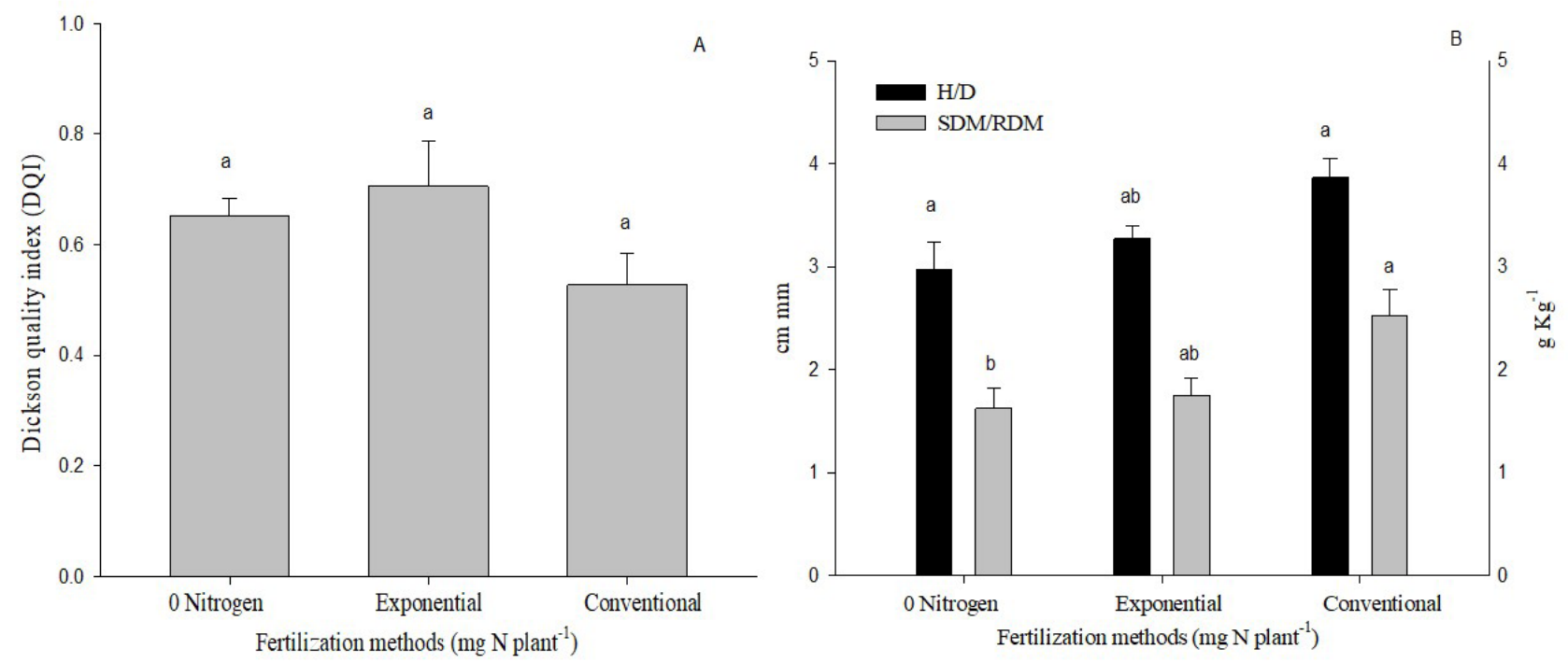

Figure 4. Dickson quality index (DQI) (A), height/diameter (H/D) ratio, shoot and root dry mass (SDM/RDM) ratio (B) from L. divaricata seedlings submitted to nitrogen fertilization treatments. Mean values followed by the same letter and the same column color do not differ among themselves by the Tukey test at $5 \%$ probability.
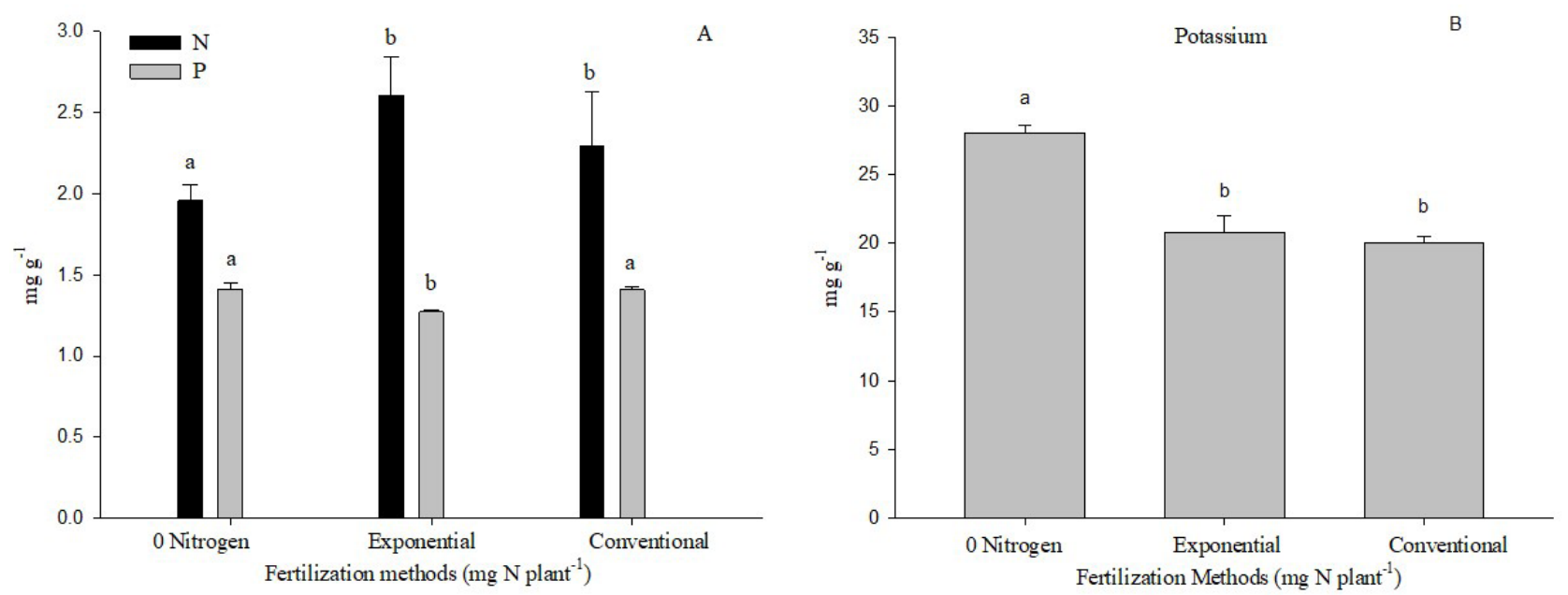

Figure 5. Leaf nitrogen $(\mathrm{N})$, phosphorus $(\mathrm{P})(\mathrm{A})$ and potassium $(\mathrm{K})$ content $(\mathrm{B})$ from L. divaricata seedlings submitted to nitrogen fertilization treatments. Mean values followed by the same letter and the same column color do not differ among themselves by the Tukey test at $5 \%$ probability.

\section{CONCLUSIONS}

Exponential and conventional fertilization regimes support the hypothesis of growth induction in L. divaricata seedlings in relation to non-fertilized seedlings.

Exponential fertilization did not induce greater growth and nutrient accumulation of $L$. divaricata seedlings when compared to conventional fertilization with the same nitrogen dose $\left(100 \mathrm{mg} \mathrm{plant}^{-1}\right)$ under experimental condition for 90 days.
Further studies are needed to assess the effects of fertilization regimes on field survival and growth, as well as the costs related to nutrient loss and demand for exponential and conventional fertilization.

\section{SUBMISSION STATUS}

Received: 28 June. 2019

Accepted: 5 June. 2020

Associate editor: João Vicente Latorraca (1) 


\section{CORRESPONDENCE TO Deisinara Giane Schulz}

Rua Sete de setembro, 156, Vila Beatriz, Nova Andradina - MS CEP: 79750-000

E-mail: deisinarags@gmail.com

\section{REFERENCES}

Caldeira MVW, Delarmelina WM, Lübe SG, Gomes DR, Gonçalves EO, Alves AF Biossólido na composição de substrato para a produção de mudas de Tectona grandis. Floresta 2012; 42(1):77-84.

Costa E, Dias JG, Lopes KG, Binotti FFS, Cardoso ED. Telas de Sombreamento e Substratos na Produção de Mudas de Dipteryx alata Vog. Floresta e Ambiente 2015; 22(3): 416-425.

Cortina J, Vilagrosa A, Trubat $\mathrm{R}$. The role of nutrients for improving seedling quality in drylands. New Forests 2013; 44:719-732.

Cruz CD. GENES: software para análise de dados em estatística experimental e em genética quantitativa. Acta Scientiarum Agronomy 2013; 35(3):271-276.

Cuesta B, Villar-Salvador P, Puértolas J, Jacobs DF, Rey-Benayas JM. Why do large, nitrogen rich seedlings better resist stressful transplanting conditions? A physiological analysis in two functionally contrasting Mediterranean forest species. Forest Ecology and Management 2010; 260:71-78.

Delarmelina WM, Caldeira MVW, Faria JCT, Gonçalves EO, Rocha RLF. Diferentes Substratos para a Produção de Mudas de Sesbania virgata. Floresta e Ambiente 2014; 21(2):224-233.

Dumroese RK, Page-Dumroese DS, Salifu KF, Jacobs DF. Exponential fertilization of Pinus monticola seedlings, nutrient uptake efficiency, leaching fractions, and early outplanting performance. Canadian Journal of Forest Research 2005; 35(12): 2961-2967.

Fu Y, Oliet JA, Li G, Wang J. Effect of controlled release fertilizer type and rate on mineral nutrients, non-structural carbohydrates, and field performance of Chinese pine container-grown seedlings. Silva Fennica 2017; 51(2): 1-13.

Grohskopf MA, Interação entre fósforo e nitrogênio em fertilizante organomineral (Tese). Botucatu: Universidade Estadual Paulista Faculdade de Ciências Agronômicas da Unesp, Botucatu, 2017.

Klooster WS, Cregg BM, Fernandez RT, Nzokou P. Growth and physiology of deciduous shade trees in response to controlled release fertilizer. Scientia Horticulturae 2012; 35:71-79.
Li G, Wang J, Oliet JA, Jacobs DF. Combined pre-hardening and fall fertilization facilitates $\mathrm{N}$ storage and field performance of Pinus tabulaeformis seedlings. iForests 2016; 9: 483-489.

López PAG, Comparación de fertilización exponencial y constante en plantulas de cinco especies forestales nativas de bosques andinos de Colombia (Tesis). Medellín: Universidad Nacional de Colombia sede Medellín. 2012.

Moreira A, Pereira JCR, Freitas AR. Nitrogênio e potássio na produtividade e qualidade da bananeira cultivar Thap Maeo. Bragantia 2009; 68(2) 483-491.

Oliet J, Planelles R, Artero F, Valverde R, Jacobs D, Segura M. Field performance of Pinus halepensis planted in Mediterranean arid conditions: relative influence of seedling morphology and mineral nutrition. New Forest 2009; 37: 313-333.

Oliet JA, Puértolas J, Planelles R, Jacobs DF. Nutrient loading of forest tree seedlings to promote stress resistance and field performance: a Mediterranean perspective. New Forests 2013; 44(5): 449-469.

Scremin-Dias E, Kalife C, Menegucci ZRH, Souza PR, Produção de mudas de espécies florestais nativas : manual. Ed. UFMS: Campo Grande MS; 2006.

Sant'ana EVP, Santos AB, Silveira PM. Adubação nitrogenada na produtividade, leitura spad e teor de nitrogênio em folhas de feijoeiro. Pesquisa Agropecuária Tropical 2010; 409 (4): 491-496.

Scheer MB, Carneiro C, Bressan OA, Santos KG. Crescimento inicial de quatro espécies florestais nativas em área degradada com diferentes níveis de calagem e de adubação. FLORESTA 2017; 47(3): 279-287.

Schmal JL, Jacobs DF, O'Reilly C. Nitrogen budgeting and quality of exponentially fertilized Quercus robur seedlings in Ireland. European Journal of Forest Research 2011; 130 (4): 557-567.

Uscola MK, Salifu1, F, Oliet, JA, Jacobs, DF. An exponential fertilization dose-response modelto promote restoration of the Mediterranean oak Quercus ilex. New Forests 2015; (46) 795-812.

Villar-Salvador P, Puértolas J, Cuesta B, Peñuelas JL, Uscola M, Heredia-Guerrero N, Rey Benayas JM. Increase in size and nitrogen concentration enhances seedling survival in Mediterranean plantations. Insights from an ecophysiological conceptual model of plant survival. New Forests 2012; 43(5): 755-770.

Villar SP, JL Puértolas, JLN Peragón, LF Benito, SD Lerena. Is nitrogen fertilization in the nursery a suitable tool for enhancing the performance of Mediterranean oak plantations? New Forests 2013; 44(5): 733-751. 